\section{Geologists as professionals}

from Peter J. Smith

Physicists, chemists, biologists and mathematicians in Britain have their respective professional institutes, and there are no less than 15 chartered institutions catering for the needs of the various types of engineer. British geologists, by contrast, have no professional body, although members of certain subdisciplines within the earth sciences are eligible to join appropriate existing organisations (some geophysicists, for example, are members of the Institute of Physics). So is there a case for the formation of a professional Institute of Geology? A working group sponsored by the Geological Society believes there is, and in its published report (Report of the Working Party on Professional Recognition, Geological Society of London; 1974) recommends that the degree of support for a professional organisation in geology be widely tested.

The Geological Society itself is a learned society, but has lately been finding it difficult to reconcile its traditional role with the need to represent British geology to the outside world. As an example of this need, the report cites the setting up in 1973 of the Council of Environmental Science and Engineering by the two councils representing, respectively, the professional science institutes and the chartered engineering institutions. Because there is no professional body of geologists affiliated to the two sponsoring councils, geologists have no formal participation in an organisation concerned with environmental problems.

Because earth science is one of the two branches of science most directly concerned with the environment, the need for a 'voice of British geology' is clearly much more than a parochial academic matter. The Geological Society working group has therefore examined in some detail the case for a professional body which "would be expected to provide representation of geological interests at different levels". But external representation is not the only, nor perhaps even the principal function of a professional institute; and it is envisaged that the proposed Institute of Geology would also operate a code of ethics and professional conduct, set professional standards for the various categories of membership, provide advice on career structures and personal security, and disseminate information on general and professional matters.

But if the idea of an Institute of Geology (by this or any other name) comes to be widely accepted, how could it be put into practice? The re- port considers five "alternative [sic] pathways" (in addition to maintenance of the status quo) but in the end rejects four of them as unlikely to succeed. The first-the creation of a professional class of Fellowship within the Geological Society-was rejected at an early stage in the discussions because although it would strengthen the society financially and allow it to speak for professional geology nationally, it would probably lead to a dissension among the ranks of the non-professional geologists (the "second class Fellowship"). Moreover, there is some doubt as to just what professional services the society would be allowed to offer under the terms of its Charter; the lack of significant additional services recently led to the failure of a similar scheme in South Africa.

Indeed, the Charter seems to be a major stumbling block, for both it and the society's grace-and-favour apartments might also be put at risk by two other possible schemes - a more thoroughgoing conversion of the society into a professional-cum-learned society (a solution adopted by the physicists) or the creation of a new body under the society's direct sponsorship. This then leaves just two other possibilities-the creation of a new body by independent sponsorship, either with no society participation or with the society's general support. The first of these is rejected because of the high costs arising from the need for administration and accommodation separate from the society and because of the possibility of conflict with the society. In the end, therefore, the working group recommends independent sponsorship with society support.

The working group is now soliciting views from as many geologists as possible, both on the idea of a professional body as such and on the proposed structure as set out in an appendix to the report. Those who respond should pay particular attention to the latter, for experience suggests that detailed organisational points which appear unimportant can, in fact, have profound consequences. For example, the working group suggests, without discussion, that the new institute should "be established as a charitable body" -an apparently innocuous enough statement. But under the present, admittedly chaotic, laws governing charitable bodies in Britain this would prevent the institute from taking part in any activity remotely political. Registration as a charity would therefore place constraints on the institute which are in many ways comparable to those now acting on the Geological Society itself. Would this be in the best interests of the geology profession?

Finally, there is at least one surprising omission from the report. The working group makes the contentious point that "the science of geology embraces many diverse fields including geophysics . . .", but fails to consider, or even mention, the anomalous position of British geophysicists within the Royal Astronomical Society. Although the working group does not regard itself "in any sense as representative", it would surely have been sensible to have had a geophysical representative of that society on the group right from the start.

\section{Ispra's 'factor up' energy programme}

THE energy crisis has done a service to both the solar and hydrogen energy projects at the largest of the European Community's Joint Research Centres, that at Ispra on Lake Maggiore, originally an exclusively Euratom establishment. The aim of the solar work, which was only initiated in 1973, is to probe promising areas not well covered either by industry or national research establishments in member countries, and a substantial increase in funding is expected this year.

The approach may be described as a 'factor-up' programme. Fundamental to work at Ispra is that solar energyalthough abundant and nonpolluting-is both diffuse and intermittent. Accepting that it is already possible to heat a house by solar energy-it is being done in the French Pyrenees through air convection generated in hollow blackened walls-Ispra is investigating higher efficiency systems. For domestic heating it is pursuing a plug-in, fixed-angle collector unit (not a house) capable of generating $100^{\circ} \mathrm{C}$ where present collectors do not surpass $65^{\circ} \mathrm{C}$, largely because of heat loss from the surface of the collector. Small scale tests of one method are in progress and these involve adaptation of the 'anti-radiation' cells developed by Francia.

A temperature of $100^{\circ} \mathrm{C}$ is a threshold value for another small scale 'domestic' application of special interest in underdeveloped arid regions. "To use the Sun to pump water out of the desert" as the brisk energy director at Ispra, Dr Joachim Gretz puts it. A heat source of this order could be coupled to a $1-\mathrm{kW}$ power set able to pump up water for 8 hours a day (during sunlight) for human and animal subsistence. Dr Gretz points out that in many areas primitive concepts of the natural world mean that communities are dying of thirst while there is pumpable water only $16-60 \mathrm{~m}$ down.

Looking further ahead Ispra sees real promise in quantum devices with which yields of $1 \mathrm{~kW} \mathrm{~m}^{-2}$ would be possible through photoelectric or photochemical conversion. 